\title{
NIPA1 wt Allele
}

National Cancer Institute

\section{Source}

National Cancer Institute. NIPA1 wt Allele. NCI Thesaurus. Code C75737.

Human NIPA1 wild-type allele is located in the vicinity of $15 q 11.2$ and is approximately 43 $\mathrm{kb}$ in length. This allele, which encodes non-imprinted in Prader-Willi/Angelman syndrome region protein 1, may play a role in nervous system development. Mutations in the gene are associated with autosomal dominant spastic paraplegia 6. 